\title{
Impact of Health and Literacy on Economic Growth in Morocco
}

\author{
Seddik BENNACEUR ${ }^{1}$ \& Boujemâa ACHCHAB $^{1}$ \\ ${ }^{1}$ Hassan 1st University, LAMSAD-ENSA Berrechid, Morocco \\ Correspondence: Seddik Bennaceur, University Hassan 1st, Higher School of Applied Sciences, BP 218, \\ Berrechid, Morocco.
}

Received: May 11, 2020

doi:10.5539/ibr.v13n7p138

\author{
Accepted: June 8, 2020 \\ Online Published: June 23, 2020
}

URL: https://doi.org/10.5539/ibr.v13n7p138

\begin{abstract}
The objective of our work is to verify the impact of the improvement of health conditions and literacy on economic growth in Morocco during the period between 1980 and 2018. We based ourselves on the work of (Mankiw et al., 1992), in which they studied the impact of human capital on economic growth by integrating it as a component in the Solow model. The data we have used mainly comes from the High Commission for Planning and the World Bank. The observation that we have made is that the composite health and literacy index that we have developed has no significant impact on the growth of GDP per capita in Morocco during the period studied, which means that the literate and healthy work force does not have the expected effect on economic growth in Morocco. Thus, to be able to take advantage of its qualified and educated workforce, we suggest that the Moroccan authorities should encourage investments in sectors of activity that require this kind of workforce, because the study of the current market situation of employment in Morocco has shown that the agricultural sector and the informal sector have a significant share in the national GDP, but recruit an illiterate or low-skilled workforce.
\end{abstract}

Keywords: human capital, economic growth, health, literacy, unemployment, Morocco

\section{Introduction}

Discussions of the importance of human capital on the process of economic growth are relatively old, according to Smith (1795) "training in all its forms improves productivity and contributes to economic progress".

The theory of human capital appeared in the sixties following the theoretical works of Mincer $(1958,1974)$, Becker (1962) and Schultz (1961) who tried to study the impact of education on individuals and the economies of the countries. Originally, this theory considered education expenditure as an investment which one sought to understand the impact on economic growth, this expenditure was considered as an efficiency factor which raised productivity and determined the level and distribution of individual gains.

At the beginning of the 1980s, and starting from the observation that many empirical estimates did not support the growth model proposed by Solow in 1956, authors like Romer (1986,1990), Lucas (1988), Barro (1991), Mankiw et al. (1992), Benhabib and Spiegel (1994) used the augmented Solow model to explain economic growth by introducing human capital in different forms as an explanatory variable for economic growth.

According to (Well, 2007), improving people's health conditions can impact countries' production levels in several different ways. On the one hand, health has a direct effect on production, because healthy people are better workers, and therefore they produce better since they can work harder and longer and think more clearly. On the other hand, health has an indirect effect on production, since healthy people are better able to continue their education and healthy students have a lower absenteeism rate and higher cognitive abilities. In addition, the reduction in the mortality rate and the increase in the life expectancy of the population encourage people to save more for their retirement, which leads to an increase in investments and the level of physical capital per worker.

In the Moroccan context, Moroccan authorities have joined several national and international programs that aim to generalize and improve the education and health conditions of the population.

At the international level, Morocco was among the countries that subscribed to the commitments to achieve the Millennium Development Goals (MDGs) over the period between 2000 and 2015, and the Sustainable Development Goals (SDGs) over the period between 2016 and 2030.

As for the national level, Morocco has launched several programs aimed at the generalization of education, the fight against the school dropouts, and the improvement of the health conditions of the population. 
Among the programs followed in the field of education, we can cite the adoption of the National Charter of Education and Training in 1999, the launch of the emergency program for the period from 2009 to 2012, the launch of a new teaching strategy called "vision 2030" in 2015, the "Tayssir" program which provides financial support to poor families in order to limit the wastage of their children's education.

As for the programs adopted in the health sector, we can cite the pregnancy and childbirth monitoring programs, the family planning program, integrated child care program ${ }^{1}$, the national program for the generalization of vaccination coverage, the program to combat micronutrient deficiencies and the promotion of infant and young child feeding, the Compulsory health insurance plan $^{2}$, the medical assistance program ${ }^{3}$ covering the disadvantaged population...

The main objective of this paper is to empirically verify to what extent human capital, approached by a composite health and literacy index, can influence economic growth in the case of the Moroccan economy. For this we took the period 1980-2018 as the time interval for our study. Thus, we will, in a first step, draw up a review of the literature which relates education and health, as components of human capital, to economic growth. In a second step, we will present the measures taken by Morocco to improve the education and health conditions of the population. In a third step, we will present the econometric model adopted in our work, as well as the description of the variables chosen and their data sources, then we will move on to the economic interpretation of the results obtained before concluding.

\section{Literature Review}

\subsection{Education and Economic Growth}

"The theory of human development is mainly based on education because it allows the accumulation of knowledge and skills" (Tilak, 1994). "The main engine of growth is the accumulation of human capital (knowledge), and the main source of difference in living standards between nations is the difference in human capital, physical capital plays an essential but decidedly secondary role" (Lucas, 1993). The theoretical works consider several ways in which education affects economic growth, on the one hand, education allows the increase of the human capital of the labor force which increases the productivity of workers and drives growth towards a higher level of balance, on the other hand, and from the point of view of the theory of endogenous growth, education allows the increase of the innovation capacity of the economy, the knowledge of new technologies and new processes production (positive externalities), which promotes economic growth (Hanushek \& Woessmann, 2008). In an empirical study on the economies of 98 countries during the period 1965-1985, Barro (1991) proved that the growth rate of real GDP per capita is positively and significantly linked to the human capital approached by the education rate of 1960 . Abdouni \& Hanchane (2004) mentioned that the role that education, measured by the gross secondary school enrollment rate, can play in the production of skills strongly depends on the degree of adaptability of the education system to the needs of the productive system. Mankiw et al. (1992) have demonstrated the existence of a positive relationship between economic growth and the working-age population attending secondary education in a sample of 121 countries studied in the period 1960-1985. By studying panel data for 21 OECD countries over the period 1971-1998, Bassanini \& Scarpetta (2001) concluded that economic growth is positively linked to the number of years of schooling. Bashir \& Darrat (1994) have shown, by studying data on the economies of 32 developing countries, that the primary school enrolment rate or the adult literacy rate has a positive and significant impact on the growth of production. Psacharopoulos (1994) has shown that the profitability of investments in primary education is a priority in developing countries and that the returns on investments in education decrease as the level of education targeted by these investments increases (the returns on investments in the primary level are higher than those in the secondary level which are also higher than those in the higher level). YEN et al. (2020) studied the Cameroonian economy during the period 1980-2016, and proved that literacy is positively and significantly correlated (at 5\% in the short and long term) with economic growth. Similarly, Gyimah-Brempong et al. (2006) studied the economies of a sample of African countries over the period 1960-2000, and came to the conclusion that investment in human capital approached by the primary, secondary and higher education has a positive and statistically significant impact on the growth rate of income per capita, and that the elasticity of income per capita with the investment in higher education is three times greater than its elasticity with the investment in physical capital. Essardi \& Razzouk (2017), by studying the Moroccan economy over the period 1965-2015, concluded that the average number of years of schooling positively and significantly affects GDP per worker. Bouoiyour (2000),

\footnotetext{
${ }^{1}$ known in Morocco as « Prise en Charge Intégrée de l'Enfant (PCIE) »

2 Known in Morocco as «Assurance Maladie Obligatoire (AMO)»

${ }^{3}$ Known in Morocco as « Régime d'Assistance Médicale (RAMed)»
} 
in a study of the Moroccan economy over the period 1958-1994, proved the existence of a short-term bidirectional causal relationship between the different levels of education (primary, secondary and higher) and economic growth, while the long-term relationship has not been confirmed. To study the relationship between social spending in the education and health sectors in Morocco between 1950 and 1985, BOUAYAD (1994) used the causality and cointegration test to prove that the GDP reacted positively to social spending. Bouoiyour \& Bennaghmouch (2002) estimated a Cobb-Douglas type function using data on Morocco covering the period 1976-1995, they used gross fixed capital formation and the education level of the workforce as explanatory variables and concluded that the education level of the workforce has a positive impact on economic growth and that this impact decreases as the level of education increases. Unlike the results of the previously cited studies, Benhabib \& Spiegel (1994) have shown that the stock of human capital (using the data elaborated by Kyriacou 1991) fails to enter significantly into the determination of economic growth and that this stock has a negative influence on economic growth, in the same direction, Bloom et al. (1998) raise an insignificant effect of the number of years of secondary school education on economic growth in 77 African countries studied during the period 1965-1990, and it is the same result mentioned by Appiah \& McMahon (2002) following the study of panel data from 52 African countries over the period 1965-1990.

To try to explain the results obtained by (Pritchett, 1996) and (Caselli et al., 1996) according to which the increase in human capital measured by the average number of years of schooling has a negative impact on economic growth, Dessus (2000) conducted a study on a panel sample made up of 83 countries between 1960 and 1990, he concluded that the estimates of (Pritchett, 1996) and (Caselli et al., 1996) suffer from a specification bias caused by the disregard of international differences in the quality of education systems, which he defined by its capacity to form an additional unit of human capital generating economic growth. he approached the quality of the education system through the educational infrastructure, the ability to distribute education equally, and the initial endowment of human capital.

\subsection{Health and Economic Growth}

"Improving the health conditions of people in developing countries not only improves people's well-being but it is potentially important for boosting productivity and growth" (World Bank, 1993). Similarly, World Health Organization (2001) mentions that the economic losses linked to bad health conditions have been underestimated, because deficits in health and education prevent countries from accessing sustained economic growth, and sub-Saharan African countries have lost at least $12 \%$ of their GNP due to the prevalence of HIV / AIDS, on the other hand, economic growth in countries not affected by malaria is at least $1 \%$ higher than in affected countries, and that the increase in life expectancy at birth by $10 \%$ corresponds to the increase of economic growth of 0.3 to $0.4 \%$ per year. In the same vein, World Health Organization (2000) announced that the economic growth of African countries has lost $1.3 \%$ per year due to malaria, and that, consequently, the GDP of these countries have a deficit of $37 \%$ compared to what it would have been in the absence of malaria. Among the works that have attempted to shed light on the relationship between health and economic growth we can cite the work of Robert William Fogel, 1993 Nobel Prize winner, who stated that about one-third of economic growth in England during the last 200 years has been due to improvements in nutrition and health (Fogel \& Wimmer, 1992). Other more recent studies have included health indicators as one of the determinants of economic growth, Barro (1996) has shown that life expectancy at birth has a positive and significant effect on economic growth. Similarly, Knowles \& Owen (1997) used the Solow model augmented by human capital (based on the work of (Mankiw et al., 1992)) and integrated the variable "life expectancy at birth" in addition to the education variable and have concluded that transnational empirical estimates show that there is a strong positive and significant relationship between economic growth and life expectancy at birth. Following the study of a panel of countries observed every 10 years during the period 1960-1990, Bloom et al. (2004) concluded that being in good health has a positive and economically significant effect on the overall productivity of workers, and that increasing life expectancy by one year increases productivity by 4\%. Similarly, Barro \& Lee (1994) studied the economies of 116 countries during the period 1965-1985 and indicate that life expectancy at birth has a positive and significant effect on economic growth and that this effect is more important than that of the secondary school enrollment rate. Ashraf et al. (2008) tested, in a sample of developing countries, the claim that improving people's health leads to increased economic growth, they concluded that increasing life expectancy from 40 to 60 years leads to an increase in GDP per capita of around 15\% in the long term. Essardi \& Razzouk (2017), by studying the Moroccan economy over the period 1965-2015, concluded that health approached by the index of the difference in life expectancy at birth between Morocco and developed countries has a positive and significant effect on GDP per capita growth. In the same vein, the study carried out by YEN et al. (2020) on the Cameroonian economy during the period 1980-2016 showed that 
health approached by life expectancy at birth has a positive and not significant relationship in the short term with GDP per capita.

\section{Measures Taken by Morocco for the Improvement of Education and Health Conditions}

\subsection{Measures Taken by Morocco in the Education Sector}

Since independence, the main aim of Moroccan authorities has been to widen access to the education and training system and improve its quality, since 1990 new approaches in the development of the education system have been adopted based on efficiency, rationalization of resources, devolution and the involvement of new partners. The results of these policies have certainly contributed to the widening of access to schooling, but in terms of quality, progress has been below expectations. Following this observation, the Special Commission for Education and Training ${ }^{4}$ was created and had the task of setting up a project to reform the Moroccan school, the work of this commission resulted in the adoption of the national charter for education and training for the period 2000-2010. In 2007 an evaluation of the results of this charter showed that the progress report remains below expectations, which prompted Moroccan authorities to reactivate the Higher Education Council ${ }^{5}$ which was responsible for monitoring and evaluating the policies adopted in the field of education and the development of the Emergency Plan for the period 2009-2012 to accelerate the implementation of the guidelines of the national charter for education and training.

In 2014 the Higher Council for Education, Training and Scientific Research was created to replace the Higher Council for Education and developed "the 2030 strategic vision", the main lines of this vision are based on three axes which are: the school of equity and equal opportunity, the school of quality for all and the school of individual and social advancement.

In addition, Morocco has joined various international programs aimed at the generalization of education and the fight against illiteracy. In fact, during the millennium summit held on the occasion of the 55th session of the general assembly of the United Nations in September 2000, 189 countries, including Morocco, subscribed to the commitment to achieve, between 2000 and 2015, the Millennium Development Goals (MDGs), this program has been followed, since September 2015, by the commitment of the international community to achieve the Sustainable Development Goals (SDGs) during the period between 2016 and 2030. These programs are divided into several objectives aimed at improving the living conditions of the population, whether in the field of poverty reduction, the fight against illiteracy, the improvement of health conditions, the fight against all kinds of discrimination, and the guarantee of a healthy global environment. Education and the fight against illiteracy have been the subject of MDG2 and ODD4, indeed MDG2 aims to ensure primary education for all, while ODD4 aims to ensure, for all, fair, inclusive, and quality education and lifelong learning opportunities.

As for financial aid, since September 2008, Moroccan authorities have launched the "Tayssir" program which provides financial support to poor families to limit wastage by fighting against certain factors that prevent the access of children of these families to education by paying them regular scholarships. The program is intended for rural communes and certain urban communes with high poverty and dropout rates.

\subsection{Measures Taken by Morocco in the Health Sector}

The component of improving the health conditions of the population was the subject of MDG4, MDG5, and MDG6 as well as SDG3. As for MDGs 4, 5 and 6, they respectively aim at reducing the mortality of children under five, improving maternal health and combating HIV/AIDS, malaria and other diseases, as far as SDG3, it aims to enable everyone to live in good health and promote the well-being of all at all ages.

To improve the health conditions of the population, Moroccan authorities have adopted several programs among which we can cite the pregnancy and childbirth monitoring programs, the family planning program, integrated child care program ${ }^{6}$, the national immunization program which aims for a vaccination coverage greater than $95 \%$ distributed uniformly at the national level, the program for the fight against micronutrient deficiencies and the promotion of infant and young child feeding.

In addition to these programs, Moroccan authorities have implemented other public policies aimed at improving health conditions of the population in general, in this sense the framework law which was adopted in 2004 by the parliament and whose implementation application was from August 2005, aims to create two health insurance

\footnotetext{
${ }^{4}$ known in Morocco as «Commission Spéciale pour l'Education et la Formation (COSEF)»

${ }^{5}$ Known in Morocco as « Conseil Supérieur de l'Enseignement (CSE)»

${ }^{6}$ known in Morocco as «Prise en Charge Intégrée de l'Enfant (PCIE) »
} 
systems: the first is a compulsory health insurance scheme ${ }^{7}$ intended for active people, as well as their dependents, and pensioners in the public and private sectors, the management of this scheme has been entrusted to the national fund of social welfare organizations ${ }^{8}$ for the public sector and the national social security fund ${ }^{9}$ for the private sector. in addition to these two systems, Moroccan authorities launched the medical assistance scheme ${ }^{10}$ covering the disadvantaged population and giving access to a basket of basic care in public health facilities for the benefit of economically weak people.

According to (Observatoire National du Développement Humain Maroc, 2017), in 2013, a year after its launch, RAMed covered nearly 3320000 people, in 2014 this workforce doubled to 6540000 beneficiaries. And according to (Agence Nationale de l'Assurance Maladie Maroc, 2016), the cumulative number of people benefiting from this scheme is 10 million, currently almost $34 \%$ of Moroccan population benefits from the services of this program.

As for maternal health, and according to National Population Survey and Family Health 2018 (Ministère de la Santé Maroc), Morocco has made significant progress during the last three decades, the maternal mortality rate has decreased by almost 66\% in twenty years, going from 332 maternal deaths per 100000 live births in 1985-1991 to 112 in 2009-2010. This decrease is mainly due to the measures taken by Morocco in the field of maternal health, in fact, the contraceptive prevalence rate among married women aged 15 to 49 years increased significantly, going from $42.5 \%$ in 1992 to $67.4 \%$ in 2011 to reach $70.8 \%$ in 2018 (results of National Population and Family Health Survey 2018). For the proportion of eight-month pregnant women who used prenatal consultation, it rose from $32 \%$ in $1987-1991$ to $77.1 \%$ in $2007-2011$, reaching $88.5 \%$ in $2014-2018$, and the proportion of births attended by skilled personnel increased during the same periods from $31 \%$ in $1987-1991$ to $73.6 \%$ in $2007-2011$ to reach $86.6 \%$ in 2014-2018.

These advances were the result of the measures taken by Moroccan authorities in the field of maternal health, which can be summarized as follows:

- The total autonomy of the national family planning program in the purchase of contraceptive products since 2001 and the acquisition of medical and technical equipment since 2005;

- The generalization of the use of women's health records since 2006;

- The gradual integration of early detection of breast and cervix cancer in primary health care since 2010 and the institutionalization of the national program for early detection of breast and cervix cancer since 2012;

- The family planning reference centers have been set up as reproductive health reference centers since 2012.

\section{Method}

\subsection{Model Specification}

To verify the relationship between human capital, in its dimensions of health and education, with economic growth in Morocco during the period between 1982 and 2018, we will base ourselves on the work of Mankiw et al. (1992), in which they studied the impact of human capital on economic growth by integrating it as a component in the Solow model, they propose a Cobb-Douglas type production function as follows:

With:

$$
Y(t)=K(t)^{\alpha} H(t)^{\beta}(A(t) L(t))^{1-\alpha-\beta}
$$

$Y(t)$ : Gross domestic product;

$K(t)$ : Physical capital stock;

$H(t)$ : Human capital stock;

$A(t)$ : Level of technical progress;

$L(t):$ Labor;

$\alpha$ and $\beta$ : parameters to be estimated.

\footnotetext{
${ }^{7}$ known in Morocco as «Assurance Maladie Obligatoire (AMO)»

${ }^{8}$ known in Morocco as «Caisse Nationale des Organismes de Prévoyance Sociale (CNOPS) »

${ }^{9}$ known in Morocco as «Caisse Nationale de Sécurité Sociale (CNSS) »

${ }^{10}$ known in Morocco as « Régime d'Assistance Médicale (RAMed)»
} 
With $\alpha+\beta<1^{11}$, which means that there is a diminishing return on the factors of production.

Factors (L) and (A) are assumed to grow exogenously at rates $\mathrm{n}$ and $\mathrm{g}$ as follows:

$$
\begin{gathered}
L(t)=L(0) e^{n t} \\
A(t)=A(0) e^{g t}
\end{gathered}
$$

And the term $\mathrm{A}(\mathrm{t}) \mathrm{L}(\mathrm{t})$ grows with a rate $\mathrm{n}+\mathrm{g}$.

We put:

$$
\begin{aligned}
& y=\frac{Y}{A L} \quad: \text { Gross domestic product per effective unit of labor; } \\
& k=\frac{K}{A L} \quad: \text { Physical capital per effective unit of Labor; } \\
& h=\frac{H}{A L} \quad: \text { Human capital per effective unit of Labor. }
\end{aligned}
$$

By replacing $\mathrm{Y}(\mathrm{t}), \mathrm{K}(\mathrm{t})$ and $\mathrm{H}(\mathrm{t})$ by their value following transformations (4), (5) and (6), equation (1) becomes:

$$
y(t)=k(t)^{\alpha} h(t)^{\beta}
$$

The functions of the accumulation of physical and human capital are given as follows:

$$
\dot{k}(t)=s_{k} y(t)-(n+g+\delta) k(t)
$$

from where:

$$
\begin{gathered}
\dot{k}(t)=s_{k} h(t)^{\alpha} k(t)^{\beta}-(n+g+\delta) k(t) \\
\dot{h}(t)=s_{h} y(t)-(n+g+\delta) h(t)
\end{gathered}
$$

from where:

$$
\dot{h}(t)=s_{h} h(t)^{\alpha} k(t)^{\beta}-(n+g+\delta) h(t)
$$

with $\delta$ is the capital depreciation rate.

Equations (8) and (9) estimate that physical capital and human capital depreciate in the same way with an equal rate .

By solving the system of equations (8) and (9) in the steady-state we obtain:

$$
\begin{aligned}
& k^{*}=\left(\frac{s_{k}^{1-\beta} s_{h}^{\beta}}{n+g+\delta}\right)^{\frac{1}{(1-\alpha-\beta)}} \\
& h^{*}=\left(\frac{s_{k}^{\alpha} s_{h}^{1-\alpha}}{n+g+\delta}\right)^{\frac{1}{(1-\alpha-\beta)}}
\end{aligned}
$$

By replacing $k^{*}$ and $h^{*}$ by their value in the production function and taking the log we obtain the equation of GDP per capita as follows:

$$
\ln \left(\frac{Y_{(t)}}{L_{(t)}}\right)=\ln A(0)+g t-\frac{\alpha+\beta}{1-\alpha-\beta} \ln (n+g+\delta)+\frac{\alpha}{1-\alpha-\beta} \ln \left(s_{k}\right)+\frac{\beta}{1-\alpha-\beta} \ln \left(s_{h}\right)
$$

As for the equation relating to technical progress, it can be written as follows:

$$
\ln A(0)=a+\varepsilon
$$

With «a» is a constant and $\varepsilon$ represents the specificities relating to countries such as the quality of institutions, good governance, the rule of law, etc.

${ }^{11}$ The opposite case $(\alpha+\beta=1)$ means that the returns to the factors of production are constant and therefore there will be no steady state. 
Thus, equation (12) becomes:

$$
\ln \left(\frac{Y_{(t)}}{L_{(t)}}\right)=a+g t-\frac{\alpha+\beta}{1-\alpha-\beta} \ln (n+g+\delta)+\frac{\alpha}{1-\alpha-\beta} \ln \left(s_{k}\right)+\frac{\beta}{1-\alpha-\beta} \ln \left(s_{h}\right)+\varepsilon
$$

Equation (14) is our basic empirical specification in this work.

\subsection{Description of Variables}

$\mathrm{n}$ : represents the rate of increase of the active population, in our specification, we will approach it by the rate of increase of the total population in Morocco between 1980 and 2018.

$\mathrm{g}$ and $\delta$ : represent respectively technical progress and capital depreciation and are considered exogenous.

$s_{k}$ : represents investment in physical capital, in our model we will approach it by the accumulation of physical capital between 1980 and 2018.

Based on the observation that the data relating to the physical capital stock is not available, we will use the perpetual inventory method (PIM) ${ }^{12}$ to build the data series from 1980 to 2018. Thus:

$$
K_{t+1}=K_{t}+I_{t}-D_{t}
$$

With:

$K_{t+1}$ : Capital stock at the beginning of year $\mathrm{t}+1$;

$K_{t}$ : Capital stock at the beginning of year $\mathrm{t}$;

$I_{t}$ : Gross fixed capital formation in year $\mathrm{t}$;

$D_{t}$ : Geometric depreciation of capital.

Under the assumption that capital depreciates at a constant rate, we can write equation (15) as follows:

$$
K_{t+1}=(1-\delta) K_{t}+I_{t}
$$

By applying equation (16) for years $\mathrm{t}, \mathrm{t}-1, \mathrm{t}-2, \ldots$ and substituting $K_{i}$ by its formula in the equation relating to period i-1 we obtain:

$$
K_{t+1}=\sum_{i=0}^{+\infty}(1-\delta)^{i} I_{t-i}
$$

If the value of the initial capital stock is known, equation (16) becomes:

$$
K_{t+1}=(1-\delta)^{t+1} K_{0}+\sum_{i=0}^{t}(1-\delta)^{i} I_{t-i}
$$

So, to be able to reconstruct the series of capital stock for the period 1980-2018, we will need the initial capital stock relative to the year $t_{0}=1980$.

In the steady-state of the economy, production increases at the same rate as the capital stock ${ }^{13}$, thus:

$$
g_{G D P}=g_{k}=\frac{K_{t+1}-K_{t}}{K_{t}}=\frac{I_{t}}{K_{t}}-\delta
$$

From where:

$$
K_{t}=\frac{I_{t}}{g_{G D P}+\delta}
$$

With:

$g_{G D P}:$ GDP growth rate;

$g_{k}:$ Capital growth rate.

The capital depreciation rate $\delta$ is assumed to be constant and equal to $5 \%{ }^{14}$.

$s_{h}$ : represents investment in human capital, it is approximated by the stock of human capital which is evaluated in its part relating to education by the rate of schooling (Barro, 1991), the average number of years of schooling of people aged 25 and over (Psacharopoulos \& Arriagada, 1986), the education level of the active population (Wolff \& Gittleman, 1993), the educational level attained and the highest diploma obtained by the active population (Bouoiyour \& Bennaghmouch, 2002), the average number of years of schooling at the primary, secondary and

12 (Eka, 2019)

13 (Harberger, 1978)

14 (Bosworth \& Collins, 2003) 
higher levels (Essardi \& Razzouk, 2017). In our model we will approach the part relating to education by the literacy rate of the population aged 15 and over (LIT_RATAE_15).

As for the part relating to health, empirical works have approached it by life expectancy at birth, (Barro \& Lee, 1994), (Barro, 1996), (Knowles \& Owen, 1997), (Bloom et al., 2004), (Essardi \& Razzouk, 2017), (YEN et al., 2020).

Life expectancy at birth is an indirect indicator of the level of satisfaction of material health needs such as healthy food, drinking water, adequate housing, good hygiene, and medical care.

In our model, we will approach the health part by the longevity index (LI) adopted by the UNDP ${ }^{15}$ since 2011 in the calculation of the human development index (HDI).

The longevity index is calculated as follows:

$\mathrm{LI}=($ life expectancy at birth - minimum value $) /(\text { maximum value }- \text { minimum value })^{16}$.

To take into account the two dimensions of human capital (longevity and literacy) we will use, like the method adopted since 2011 by the UNDP for calculating the $\mathrm{HDI}^{17}$, a composite indicator of health and literacy (HEALTH_LITERACY_INDEX) which is equal to the geometric mean of the longevity index (LI) and the literacy rate of the population aged 15 and over (LIT_RATAE_15).

$$
\text { HEALTH_LITERACY_INDEX }=\sqrt{L I * L I T \_R A T E \_15}
$$

\subsection{Data Sources}

Table 1. Variables and data sources

\begin{tabular}{|l|l|}
\hline Variable & Source \\
\hline GDP in constant Moroccan dirham of 2007 & High Commission for Planning (HCP Morocco) \\
\hline GFCF in constant Moroccan dirham of 2007 & High Commission for Planning (HCP Morocco) \\
\hline Capital stock & $\begin{array}{l}\text { Calculated by the author from the GDP and GFCF data prepared by the } \\
\text { HCP Morocco }\end{array}$ \\
\hline Literacy rate of the population aged 15 and over & $\begin{array}{l}\text { World development indicators and annual reports of the national } \\
\text { employment survey carried out by the HCP Morocco }\end{array}$ \\
\hline Life expectancy at birth & World development indicators \\
\hline Total population & World development indicators \\
\hline Total population growth rate & $\begin{array}{l}\text { Calculated by the author from the total population data compiled by } \\
\text { WDI }\end{array}$ \\
\hline
\end{tabular}

\section{Results}

\section{Econometric estimation}

Stationarity study of variables with the ADF test and KPSS test:

- GDP per capita 'GDP_PER_CAPITA':

-ADF test reveals the existence of a unit root for the variable LOG_GDP_PER_CAPITA at the level, and that this variable becomes stationary only in first difference (D (LOG_GDP_PER_CAPITA)). (Table 4 in appendix).

-KPSS test reveals the existence of a unit root for the variable LOG_GDP_PER_CAPITA at the level, and that this variable becomes stationary only in first difference (D (LOG_GDP_PER_CAPITA)). (Table 5 in appendix).

- Physical capital stock 'CAPITAL_STOCK':

-ADF test reveals the existence of a unit root for the variable LOG_CAPITAL_STOCK at the level and in first difference, and that this variable becomes stationary only in second difference (D (LOG_CAPITAL_STOCK, 2)). (Table 6 in appendix).

-KPSS test reveals the existence of a unit root for the variable LOG_CAPITAL_STOCK at the level, and that this

${ }^{15}$ United Nations Development Program

16 The averages of the maximum and minimum value of life expectancy at birth are defined by the UNDP at 83.4 and 20 years respectively.

17 The formula adopted by the UNDP for calculating the HDI since 2011 is:

$$
H D I=\sqrt[3]{I_{\text {life }} * I_{\text {education }} * I_{\text {income }}}
$$


variable becomes stationary only in first difference (D (LOG_CAPITAL_STOCK)). (Table 7 in appendix).

- Population growth rate 'POP_GROWTH':

-ADF test reveals the existence of a unit root for the variable LOG_POP_GROWTH at the level and in first difference, and that this variable becomes stationary only in second difference (D (LOG_POP_GROWTH, 2)). (Table 8 in appendix).

-KPSS test reveals the existence of a unit root for the variable LOG_POP_GROWTH at the level, and that this variable becomes stationary only in first difference (D (LOG_POP_GROWTH)). (Table 9 in appendix).

- Composite health and literacy index 'HEALTH_LITERACY_INDEX':

-ADF test reveals the existence of a unit root for the variable LOG_HEALTH_LITERACY_INDEX at the level, and that this variable becomes stationary only in first difference (D (LOG_HEALTH_LITERACY_INDEX)). (Table 10 in appendix).

- KPSS test reveals the existence of a unit root for the variable LOG_HEALTH_LITERACY_INDEX at the level, and that this variable becomes stationary only in first difference (D (LOG_HEALTH_LITERACY_INDEX)). (Table 11 in appendix).

Decision: Unit root tests have shown that the variables are not stationary in level.

The results of our econometric estimate are shown in the table below:

Table 2. Results of regression: Dependent Variable GDP per Capita (D1_LOG_GDP_PER_CAPITA)

Sample: 19802018

Sample (adjusted): 19822018

Included observations: 37 after adjustments

\begin{tabular}{|c|c|c|c|c|}
\hline Independent variable & Abbreviation & $\begin{array}{c}\text { Coefficient (Std. } \\
\text { Error) }\end{array}$ & t-Statistic & p-values \\
\hline Constant & C & $\begin{array}{c}0.056019 \\
(0.010709)\end{array}$ & 5.230821 & 0.0000 \\
\hline Physical capital stock & D2_LOG_CAPITAL_STOCK & $\begin{array}{c}4.589784 \\
(0.619300)\end{array}$ & 7.411250 & 0.0000 \\
\hline Population growth & D2_LOG_POP_GROWTH & $\begin{array}{c}-1.271209 \\
(0.667487)\end{array}$ & -1.904471 & 0.0656 \\
\hline $\begin{array}{c}\text { Composite health and literacy } \\
\text { index }\end{array}$ & D1_LOG_HEALTH_LITERA & $\begin{array}{c}-0.058098 \\
(0.400492)\end{array}$ & -0.145066 & 0.8855 \\
\hline
\end{tabular}

Before proceeding to the interpretation of the results of our regression we will first interpret the necessary tests:

- Detection of multicollinearity of the independent variables:

the values of centered variance inflation factor (VIF) relative to all the independent variables are low, which means that there is no multicollinearity. (Table 12 in appendix).

- Cointegration test:

Johansen's test shows that there is no cointegration relation between the variables. (Table 13 in appendix).

- Stability of the model:

CUSUM of squares test showed that our model is stable, since the curve of the cumulative sum of squares does not exceed the 5\% significance level boundaries. (Figure 3 in appendix).

- Residuals normality test:

The probability of the Jarque-bera statistic is equal to 0.689609 which is greater than 0.05 , which means that the null hypothesis (the residuals follow a normal distribution) is accepted. (Figure 2 in appendix).

- Heteroskedasticity test for the variances of the residuals:

The Breusch-Pagan-Godfrey test reveals that the variances of the residuals are homoscedastic, indeed the fisher statistic has a p-value equal to 0.7829 which is greater than 0.05 , which means that the null hypothesis (absence of heteroscedasticity) is accepted. (Table 14 in appendix). 
- Residuals autocorrelation test:

The Breusch-Godfrey test reveals that the residuals are not autocorrelated since the p-value of the Fisher statistic is equal to 0.1479 which is greater than 0.05 , thus the null hypothesis (absence of autocorrelation) is accepted. (Table 15 in appendix).

\section{Discussion}

The overall significance of the model is good since the coefficient of determination is equal to $64.03 \%$.

Regarding the stock of physical capital, it significantly explains the GDP per capita since it has a positive impact and highly significant with a coefficient equal to 4.59 and a p-value equal to 0 , so any increase in the stock of physical capital by $1 \%$ will generate an increase in GDP per capita of $4.59 \%$.

As for the population growth rate, it has a negative and significant impact at the level of $10 \%$ on GDP per capita, since its coefficient is equal to -1.27 with a p-value equal to 0.0656 , so any increase in the population growth rate by $1 \%$ will generate a decrease in GDP per capita of $1.27 \%$. This observation is in line with the theoretical specification of (Mankiw et al., 1992) which indicate that population growth has a negative effect on GDP per capita.

Regarding the composite health and literacy index, and contrary to the expected effect of this variable, the model shows that it has a negative and not significant effect on GDP per capita, since its coefficient is equal at -0.058 and not significant since its p-value is equal to 0.8855 .

The variable "HEALTH_LITERACY_INDEX" gives us an idea of literacy and population health, so the estimation of the model means that the Moroccan economy does not take enough advantage of the potential of its educated and healthy workforce. This can be explained by the problem of the mismatch between training and the needs of the labor market ${ }^{18}$, or by the inability of Moroccan economic to absorb the educated workforce. Indeed, the study of the job market in Morocco according to the results of the general census of population and housing of 2014 «GCPH2014», demonstrates that Moroccan economy absorbs the non-qualified population better since $52.2 \%$ of the employed active population has no diploma, and only 7.7\% have a higher education diploma (bachelor, university degree, diploma of in-depth studies ${ }^{19}$, Graduate Diploma ${ }^{20}$, Master, Ph.D., engineer and senior managers), and only $9.8 \%$ have a vocational training diploma. The table below shows the situation of the job market in Morocco according to the diploma obtained.

Table 3. Employed working population by general education and vocational training diploma obtained

\begin{tabular}{|l|c|}
\hline Diplomas & employed labor in \% \\
\hline Without diploma & 52.2 \\
\hline General education degrees & $\mathbf{3 8 . 0}$ \\
\hline Primary & 18.1 \\
\hline College secondary & 8.2 \\
\hline Secondary qualifying & 3.9 \\
\hline Bachelor's Degree & 0.7 \\
\hline University degree & 4.3 \\
\hline DEA/DES/Master & 1.1 \\
\hline Ph.D. & 0.9 \\
\hline engineer and senior managers & 0.7 \\
\hline Professional training diplomas & $\mathbf{9 . 8}$ \\
\hline Specialized technicians & 2.0 \\
\hline Technician / Middle management & 3.0 \\
\hline Professional qualification & 3.4 \\
\hline Professional specialization & 0.9 \\
\hline Professional initiation & 0.5 \\
\hline Diploma not declared & 0.0 \\
\hline Total & $\mathbf{1 0 0 . 0}$ \\
\hline Source : ladequation entre & Plan (HCP) \\
\hline
\end{tabular}

Source : l'adéquation entre formation et emploi au Maroc. Haut Commissariat au Plan (HCP) Maroc.

18 (Abdouni \& Hanchane, 2004): The role that education can play in the production of skills strongly depends on the degree of adaptability of the education system to the needs of the productive system.

19 known in Morocco as « Diplôme des Etudes Approfondies (DEA)»

${ }^{20}$ known in Morocco as «Diplôme des Etudes Supérieures (DES) » 
On the other hand, the study of the unemployment rate according to the diploma obtained reveals that the active population without a diploma manages to land a job more easily than the literate population (all levels combined), since the unemployment rate relative to the active population without any diploma is of the order of $11.2 \%$, this rate is lower than that recorded for the working population having a general education diploma and for the population having a Professional training diploma which respectively record rates of $19.7 \%$ and $25.5 \%$.

In addition, Moroccan economy does not make optimal use of the capacities of its active working population, indeed, and always according to the results of the GCPH2014, only $45.7 \%$ of the active working literate are in a situation of adequacy, that is to say that they exercise jobs adapted to their level of education. While $54.3 \%$ are in a situation of inadequacy since $46.7 \%$ are in a situation of upgrading (they exercise jobs which require levels of education higher than their level) and $7.6 \%$ are in a downgrading situation (they work in jobs which require educational levels below their level).

Figure 1 shows the adequacy, downgrading, and upgrading rates of the employed labor force in Morocco according to the results of the GCPH2014:

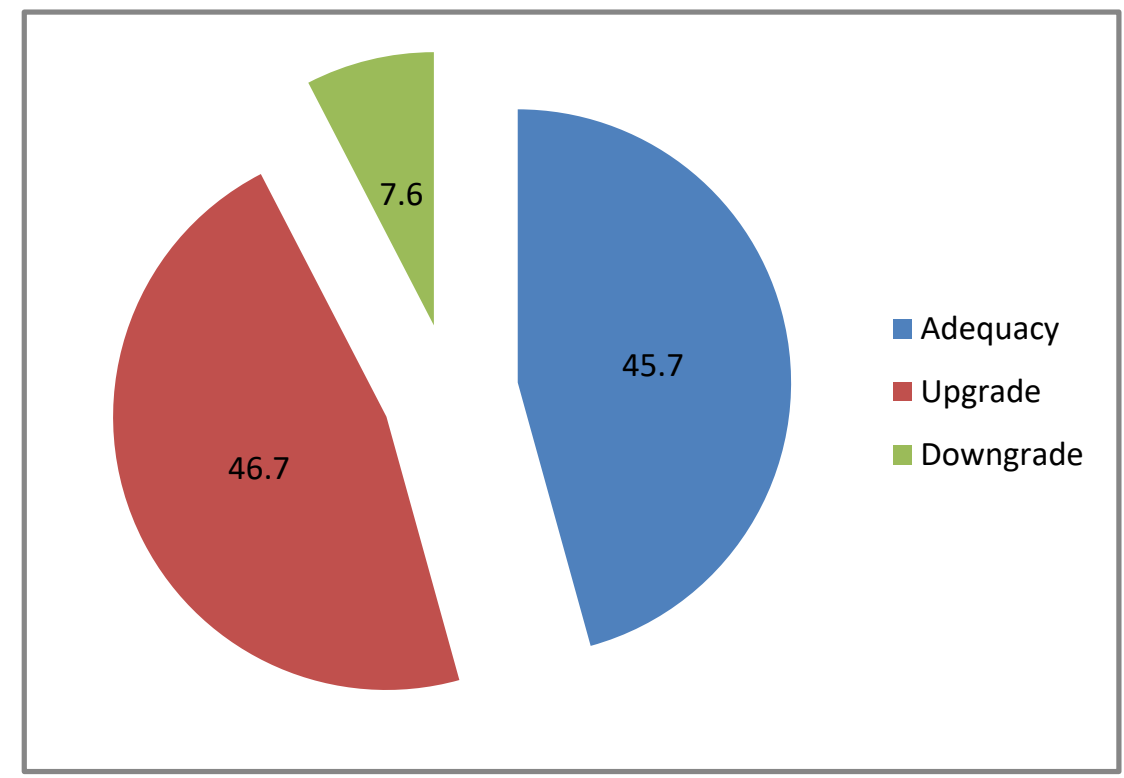

Figure 1. Rate (in\%) of adequacy, downgrading and upgrading of the employed active population in Morocco according to the results of the GCPH2014

Source: l'adéquation entre formation et emploi au Maroc. Haut Commissariat au Plan (HCP) Maroc.

In addition, the informal sector and the agricultural sector, and despite the importance of their contribution to the national GDP, they absorb more the illiterate or low-skilled labor force. Indeed, according to the results of the national survey on the informal sector carried out by the HCP between 2013 and 2014, informal non-agricultural production units contributed around 11.5\% of national GDP in 2013 (basic prices 2007), while more than two-thirds of informal entrepreneurs attended only pre-school and primary education. As for agriculture, despite representing an important provider of employment ${ }^{21}$ and contributing more than $11 \%$ to the national GDP ${ }^{22}$, it remains generally characterized by the recruitment of illiterate or low-skilled labor.

Thus, to be able to take advantage of its qualified and educated workforce, we suggest that the Moroccan authorities should encourage investments in sectors of activity that require this kind of workforce.

\section{Conclusion}

To measure the impact of investment in human capital on the growth of GDP per capita in Morocco, we have

${ }^{21}$ According to the HCP, the percentage of the employed labor force working in the agriculture sector was $45.9 \%$ in $2000,45.2 \%$ in $2005,40.3 \%$ in $2010,39 \%$ in 2015.

${ }^{22}$ According to the HCP, the contribution of the agricultural sector to national GDP in volume was $11.58 \%$ in $2010,12.80 \%$ in 2017 and $12.92 \%$ in 2018. 
approached the health and literacy dimensions of human capital in Morocco by a composite index in the form of a geometric mean of the literacy rate of the population aged 15 and over and the longevity index, the observation revealed by the theoretical and empirical approach that we adopted in our work is that the composite index of health and literacy has no significant impact on the growth of GDP per capita in Morocco during the period studied, which means that the literate and healthy work force does not have the expected effect on economic growth in Morocco, indeed the analysis of Moroccan market employment has shown that educated young people have more difficulties finding a job than those who are illiterate, in addition, by analyzing the employed labor force, we highlight two main observations, the first is that the non-graduate population is dominant compared to the population with higher levels of education, the second is that the majority of the employed active population is not used in an optimal way, since more than half of this population (54.3\%) is in a situation of inadequacy either by upgrading or downgrading. In addition, the employed working population, working in the agricultural and informal sectors which have a very important contribution to the national GDP, is mainly illiterate or having a low level of education. Thus, we suggest that the Moroccan authorities should encourage investments in sectors of activity that require a qualified and educated workforce.

\section{References}

Abdouni, A., \& Hanchane, S. (2008). A la recherche des liens hétérogènes entre l'ouverture, le capital humain et la croissance économique dans les pays en voie de développement: un examen à l'aide des données de panel. Critique économique: La revue des économistes critiques. IMIST, service de coopération et d'action culturelle de l'ambassade de france au maroc, 9, 99-130.

Agence Nationale de l'Assurance Maladie Maroc. (2016). Rapport d'activités de l'Agence Nationale de l'Assurance Maladie (ANAM).

Appiah, E. N., \& McMahon, W. W. (2002). The social outcomes of education and feedbacks on growth in Africa. Journal of Development Studies, 38(4), 27-68. https://doi.org/10.1080/00220380412331322411

Ashraf, Q. H., Lester, A., \& Weil, D. N. (2008). When does improving health raise GDP? NBER Macroeconomics Annual, 23(1), 157-204. https://doi.org/10.1086/593084

Barro, R. (1996). Health and economic growth. World Health Organization.

Barro, R. J. (1991). Economic growth in a cross section of countries. The Quarterly Journal of Economics, 106(2), 407-443. https://doi.org/10.2307/2937943

Barro, R. J., \& Lee, J. W. (1994). Sources of economic growth. Carnegie-Rochester Conference Series on Public Policy, 40, 1-46. https://doi.org/10.1016/0167-2231(94)90002-7

Bashir, A. H. M., \& Darrat, A. F. (1994). Human capital, investment and growth: Some results from an endogenous growth model. Journal of Economics and Finance, 18(1), 67-80. https://doi.org/10.1007/BF02920223

Bassanini, A., \& Scarpetta, S. (2001). Does human capital matter for growth in OECD countries? Evidence from pooled mean-group estimates. https://doi.org/10.2139/ssrn.265364

Becker, G. S. (1962). Investment in human capital: A theoretical analysis. Journal of political economy, 70, 9-49. https://doi.org/10.1086/258724

Benhabib, J., \& Spiegel, M. M. (1994). The role of human capital in economic development evidence from aggregate cross-country data. Journal of Monetary Economics, 34(2), 143-173. https://doi.org/10.1016/0304-3932(94)90047-7

Bloom, D. E., Canning, D., \& Sevilla, J. (2004). The effect of health on economic growth: A production function approach. World Development, 32(1), 1-13. https://doi.org/10.1016/j.worlddev.2003.07.002

Bloom, D. E., Sachs, J. D., Collier, P., \& Udry, C. (1998). Geography, demography, and economic growth in Africa. Brookings Papers on Economic Activity, 1998(2), 207-295. https://doi.org/10.2307/2534695

Bosworth, B., \& Collins, S. M. (2003). The empirics of growth: An update. Brookings Papers on Economic Activity, 2003(2), 113-206. https://doi.org/10.1353/eca.2004.0002

Bouayad, A. (1994). Capital humain et croissance des pays en développement : Le cas du maroc [PhD Thesis]. Toulouse 1.

Bouoiyour, J. (2000). Relation éducation croissance économique au Maroc Long terme ou court terme ? tech.rep. University Library of Munich, Germany. 
Bouoiyour, J., \& Bennaghmouch, S. (2002). Capital humain et croissance économique au Maroc. tech.rep University Library of Munich, Germany.

Caselli, F., Esquivel, G., \& Lefort, F. (1996). Reopening the convergence debate: A new look at cross-country growth empirics. Journal of Economic Growth, 1(3), 363-389. https://doi.org/10.1007/BF00141044

Dessus, S. (2000). Capital humain et croissance: Le rôle retrouvé du système éducatif. Économie Publique/Public Economics, 2(6), 95-115.

Eka, F. (2019). IDE chinois et croissance économique des pays d'Afrique sub-saharienne: Méthode PIM et régression quantile des données en panel. hal-02141051

Essardi, O., \& Razzouk, R. (2017). Human capital and economic growth in Morocco: Evidence from bayesian model averaging. International Business Research, 10(12), 167-182. https://doi.org/10.5539/ibr.v10n12p167

Fogel, R., \& Wimmer, L. (1992). Early Indicators of Later Work Levels, Disease, and Death. National Bureau of Economic Research historical paper No 38. https://doi.org/10.3386/h0038

Gyimah-Brempong, K., Paddison, O., \& Mitiku, W. (2006). Higher education and economic growth in Africa. The Journal of Development Studies, 42(3), 509-529. https://doi.org/10.1080/00220380600576490

Hanushek, E. A., \& Woessmann, L. (2008). The role of cognitive skills in economic development. Journal of Economic Literature, 46(3), 607-668. https://doi.org/10.1257/jel.46.3.607

Harberger, A. C. (1978). On the use of distributional weights in social cost-benefit analysis. Journal of Political Economy, 86(2, Part 2), S87-S120. https://doi.org/10.1086/260696

Haut Commissariat au Plan (HCP) Maroc. L'ADEQUATION ENTRE FORMATION ET EMPLOI AU MAROC.

Knowles, S., \& Owen, P. D. (1997). Education and health in an effective-labour empirical growth model. Economic Record, 73(223), 314-328. https://doi.org/10.1111/j.1475-4932.1997.tb01005.x

Lucas, R. E. (1988). On the mechanics of economic development. Journal of monetary economics, 22, 3-42. https://doi.org/10.1016/0304-3932(88)90168-7

Lucas Jr, R. E. (1993). Making a miracle. Econometrica: Journal of the Econometric Society, 251-272.

Mankiw, N. G., Romer, D., \& Weil, D. N. (1992). A contribution to the empirics of economic growth. The Quarterly Journal of Economics, 107(2), 407-437. https://doi.org/10.2307/2118477

Mincer, J. (1958). Investment in human capital and personal income distribution. Journal of political economy, 66, 281-302. https://doi.org/10.1086/258055

Mincer, J. (1974). Schooling, Experience, and Earnings. Human Behavior \& Social Institutions No. 2.

Ministère de la Santé Maroc. Enquête Nationale sur la Population et la Santé Familiale (ENPSF)-2018 (RAPPORT PRELIMINAIRE).

Observatoire National du Développement Humain Maroc. (2017). Evaluation du Régime d'Assistance Médicale aux économiquement démunis (RAMed) Rapport.

Pritchett, L. (1996). Where has all the education gone? The World Bank. Policy Research Working Paper, 1581. https://doi.org/10.1596/1813-9450-1581

Psacharopoulos, G. (1994). Returns to investment in education: A global update. World Development, 22(9), 1325-1343. https://doi.org/10.1016/0305-750x(94)90007-8

Psacharopoulos, G., \& Arriagada, A. M. (1986). The educational composition of the labour force: An international comparison. Int'l Lab. Rev., 125, 561.

Romer, P. M. (1986). Increasing returns and long-run growth. Journal of political economy, 94, 1002-1037. https://doi.org/10.1086/261420

Romer, P. M. (1990). Endogenous technological change. Journal of political Economy, 98, S71-S102. https://doi.org/10.1086/261725

Schultz, T. W. (1961). Investment in human capital. The American economic review, 51, 1-17

Smith, A. (1795). history of astronomy, in essays on philosophical subjects. londres,Cadell and Davis, cited by Amartya S (2000).

Tilak, J. B. (1994). South Asian perspectives. International Journal of Educational Research, 21(8), 791-798. 
https://doi.org/10.1016/0883-0355(94)90005-1

Well, D. N. (2007). Accounting for the effect of health on economic growth. The Quarterly Journal of Economics, 122(3), 1265-1306. https://doi.org/10.1162/qjec.122.3.1265

Wolff, E., \& Gittleman, M. (1993). The role of education in productivity convergence: Does higher education matter? In Explaining economic growth (pp. 147-167). Elsevier Science Publishers.

World Bank. (1993). WORLD DEVELOPMENT REPORT 1993 Investing in health.

World Health Organization. (2000). La Déclaration d'Abuja et le plan d'action.

World Health Organization. (2001). Macroeconomics and Health: Investing in Health for Economic Development.

YEN, G. B. D., SONKENG, G., \& OUMBE, H. T. (2020). Alphabétisation et santé comme vecteurs de croissance économique au Cameroun. Repères et Perspectives Economiques, 4(6).

\section{Appendix}

Table 4. Stationarity study of the variable LOG_GDP_PER_CAPITA (ADF test)

Null Hypothesis: D(LOG_GDP_PER_CAPITA) has a unit root
Exogenous: Constant
\begin{tabular}{llll} 
Lag Length: 0 (Automatic - based on SIC, maxlag=9) & & \\
\hline & t-Statistic & Prob.* \\
\hline Augmented Dickey-Fuller test statistic & -7.793911 & 0.0000 \\
\hline Test critical values: & 5\% level & -3.621023 & \\
& -2.943427 & \\
& -2.610263 & \\
\end{tabular}

*MacKinnon (1996) one-sided p-values.

Table 5. Stationarity study of the variable LOG_GDP_PER_CAPITA (KPSS test)

\begin{tabular}{|c|c|c|}
\hline \multicolumn{3}{|c|}{ Null Hypothesis: D(LOG_GDP_PER_CAPITA) is stationary } \\
\hline \multicolumn{3}{|l|}{ Exogenous: Constant } \\
\hline \multicolumn{3}{|c|}{ Bandwidth: 3 (Newey-West automatic) using Bartlett kernel } \\
\hline & & LM-Stat. \\
\hline \multicolumn{2}{|c|}{ Kwiatkowski-Phillips-Schmidt-Shin test statistic } & 0.344890 \\
\hline \multirow[t]{3}{*}{ Asymptotic critical values*: } & $1 \%$ level & 0.739000 \\
\hline & $5 \%$ level & 0.463000 \\
\hline & $10 \%$ level & 0.347000 \\
\hline
\end{tabular}

*Kwiatkowski-Phillips-Schmidt-Shin (1992, Table 1) 
Table 6. Stationarity study of the variable LOG_CAPITAL_STOCK (ADF test)

Null Hypothesis: D(LOG_CAPITAL_STOCK,2) has a unit root

Exogenous: Constant

Lag Length: 0 (Automatic - based on SIC, maxlag=9)

\begin{tabular}{lccc}
\hline & t-Statistic & Prob.* \\
\hline Augmented Dickey-Fuller test statistic & -6.120867 & 0.0000 \\
\hline Test critical values: & $1 \%$ level & -3.626784 & \\
$5 \%$ level & -2.945842 & \\
$10 \%$ level & -2.611531 & \\
\hline
\end{tabular}

*MacKinnon (1996) one-sided p-values.

Table 7. Stationarity study of the variable LOG_CAPITAL_STOCK (KPSS test)

Null Hypothesis: D(LOG_CAPITAL_STOCK) is stationary

Exogenous: Constant

Bandwidth: 3 (Newey-West automatic) using Bartlett kernel

LM-Stat.

\begin{tabular}{|c|c|c|}
\hline \multicolumn{2}{|c|}{ Kwiatkowski-Phillips-Schmidt-Shin test statistic } & \multirow{2}{*}{$\frac{0.122256}{0.739000}$} \\
\hline Asymptotic critical values*: & $1 \%$ level & \\
\hline & $5 \%$ level & 0.463000 \\
\hline & $10 \%$ level & 0.347000 \\
\hline
\end{tabular}

*Kwiatkowski-Phillips-Schmidt-Shin (1992, Table 1)

Table 8. Stationarity study of the variable LOG_POP_GROWTH (ADF test)

Null Hypothesis: D(LOG_POP_GROWTH,2) has a unit root

Exogenous: Constant

Lag Length: 1 (Automatic - based on SIC, maxlag=9)

\begin{tabular}{lccc}
\hline & t-Statistic & Prob.* \\
\hline Augmented Dickey-Fuller test statistic & -4.526440 & 0.0009 \\
\hline Test critical values: & $1 \%$ level & -3.632900 & \\
$5 \%$ level & -2.948404 & \\
$10 \%$ level & -2.612874 & \\
\hline
\end{tabular}

*MacKinnon (1996) one-sided p-values. 
Table 9. Stationarity study of the variable LOG_POP_GROWTH (KPSS test)

\begin{tabular}{|c|c|c|}
\hline \multicolumn{3}{|c|}{ Null Hypothesis: D(LOG_POP_GROWTH) is stationary } \\
\hline \multicolumn{3}{|l|}{ Exogenous: Constant } \\
\hline \multicolumn{3}{|c|}{ Bandwidth: 5 (Newey-West automatic) using Bartlett kernel } \\
\hline & & LM-Stat. \\
\hline \multicolumn{2}{|c|}{ Kwiatkowski-Phillips-Schmidt-Shin test statistic } & 0.260029 \\
\hline \multirow[t]{3}{*}{ Asymptotic critical values*: } & $1 \%$ level & 0.739000 \\
\hline & $5 \%$ level & 0.463000 \\
\hline & $10 \%$ level & 0.347000 \\
\hline
\end{tabular}

*Kwiatkowski-Phillips-Schmidt-Shin (1992, Table 1)

Table 10. Stationarity study of the variable LOG_HEALTH_LITERACY_INDEX (ADF test)

Null Hypothesis: D(LOG_HEALTH_LITERACY_INDEX) has a unit root

Exogenous: Constant

Lag Length: 0 (Automatic - based on SIC, maxlag=9)

\begin{tabular}{llcc}
\hline & & t-Statistic & Prob.* \\
\hline Augmented Dickey-Fuller test statistic & & -6.508358 & 0.0000 \\
Test critical values: & $1 \%$ level & -3.621023 & \\
& $5 \%$ level & -2.943427 & \\
& $10 \%$ level & -2.610263 & \\
\hline
\end{tabular}

*MacKinnon (1996) one-sided p-values.

Table 11. Stationarity study of the variable LOG_HEALTH_LITERACY_INDEX (KPSS test)

Null Hypothesis: D(LOG_HEALTH_LITERACY_INDEX) is stationary

Exogenous: Constant

Bandwidth: 3 (Newey-West automatic) using Bartlett kernel

LM-Stat.

\begin{tabular}{lcc}
\hline Kwiatkowski-Phillips-Schmidt-Shin test statistic & 0.416004 \\
\hline Asymptotic critical values*: & $1 \%$ level & 0.739000 \\
& $5 \%$ level & 0.463000 \\
& $10 \%$ level & 0.347000 \\
\hline
\end{tabular}

*Kwiatkowski-Phillips-Schmidt-Shin (1992, Table 1) 
Table 12. Test of multicollinearity of the independent variables

Variance Inflation Factors

Sample: 19802018

Included observations: 37

\begin{tabular}{cccc}
\hline Variable & Coefficient & Uncentered \\
Variance & VIF & Centered \\
VIF & NA \\
C & 0.000115 & 2.218367 & 1.059684 \\
D2_LOG_CAPITAL_STOCK & 0.383532 & 1.059693 & 1.015222 \\
D2_LOG_POP_GROWTH & 0.445539 & 1.024956 & 1.061104 \\
\hline D1_LOG_HEALTH_LITERACY_INDEX & 0.160394 & 2.250899 & \\
\hline
\end{tabular}

Table 13. Johansen cointegration test

\begin{tabular}{|c|c|c|c|c|}
\hline \multicolumn{5}{|c|}{ Sample (adjusted): 19822018} \\
\hline \multicolumn{5}{|c|}{ Included observations: 37 after adjustments } \\
\hline \multicolumn{5}{|c|}{ Trend assumption: Linear deterministic trend } \\
\hline \multicolumn{5}{|c|}{ Series: CAPITAL_STOCK GDP_PER_CAPITA HEALTH_LITERACY_INDEX } \\
\hline \multicolumn{5}{|c|}{ POP_GROWTH } \\
\hline \multicolumn{5}{|c|}{ Lags interval (in first differences): 1 to 1} \\
\hline \multicolumn{5}{|c|}{ Unrestricted Cointegration Rank Test (Trace) } \\
\hline Hypothesized & & Trace & 0.05 & \\
\hline No. of CE(s) & Eigenvalue & Statistic & Critical Value & Prob.** \\
\hline None & 0.448862 & 42.71674 & 47.85613 & 0.1396 \\
\hline At most 1 & 0.312660 & 20.67324 & 29.79707 & 0.3783 \\
\hline At most 2 & 0.167900 & 6.800992 & 15.49471 & 0.6009 \\
\hline At most 3 & $8.18 \mathrm{E}-06$ & 0.000303 & 3.841466 & 0.9882 \\
\hline \multicolumn{5}{|c|}{ Trace test indicates no cointegration at the 0.05 level } \\
\hline \multicolumn{5}{|c|}{$*$ denotes rejection of the hypothesis at the 0.05 level } \\
\hline \multicolumn{5}{|c|}{ **MacKinnon-Haug-Michelis (1999) p-values } \\
\hline
\end{tabular}

Table 14. Heteroskedasticity Test: Breusch-Pagan-Godfrey

\begin{tabular}{llll}
\hline F-statistic & 0.359143 & Prob. F(3,33) & 0.7829 \\
Obs*R-squared & 1.169831 & Prob. Chi-Square(3) & 0.7602 \\
Scaled explained SS & 0.880275 & Prob. Chi-Square(3) & 0.8302 \\
\hline
\end{tabular}


Table 15. Breusch-Godfrey Serial Correlation LM Test

\begin{tabular}{llll}
\hline F-statistic & 2.034135 & Prob. F(2,31) & 0.1479 \\
Obs*R-squared & 4.292369 & Prob. Chi-Square(2) & 0.1169
\end{tabular}

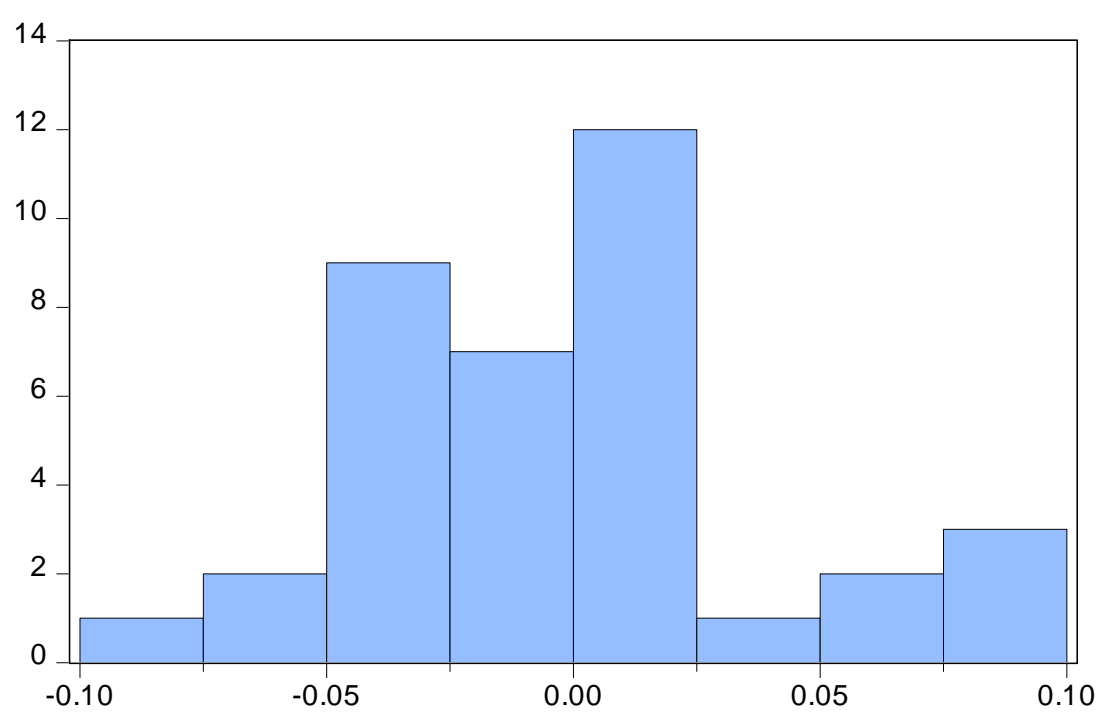

\begin{tabular}{|ll|}
\hline \multicolumn{2}{|l|}{ Series: Residuals } \\
Sample 1982 2018 \\
Observations 37 \\
Mean & $-9.38 \mathrm{e}-18$ \\
Median & -0.001455 \\
Maximum & 0.090337 \\
Minimum & -0.091657 \\
Std. Dev. & 0.041875 \\
Skewness & 0.342941 \\
Kurtosis & 2.891911 \\
& \\
Jarque-Bera & 0.743262 \\
Probability & 0.689609 \\
\hline
\end{tabular}

Figure 2. Residuals normality test

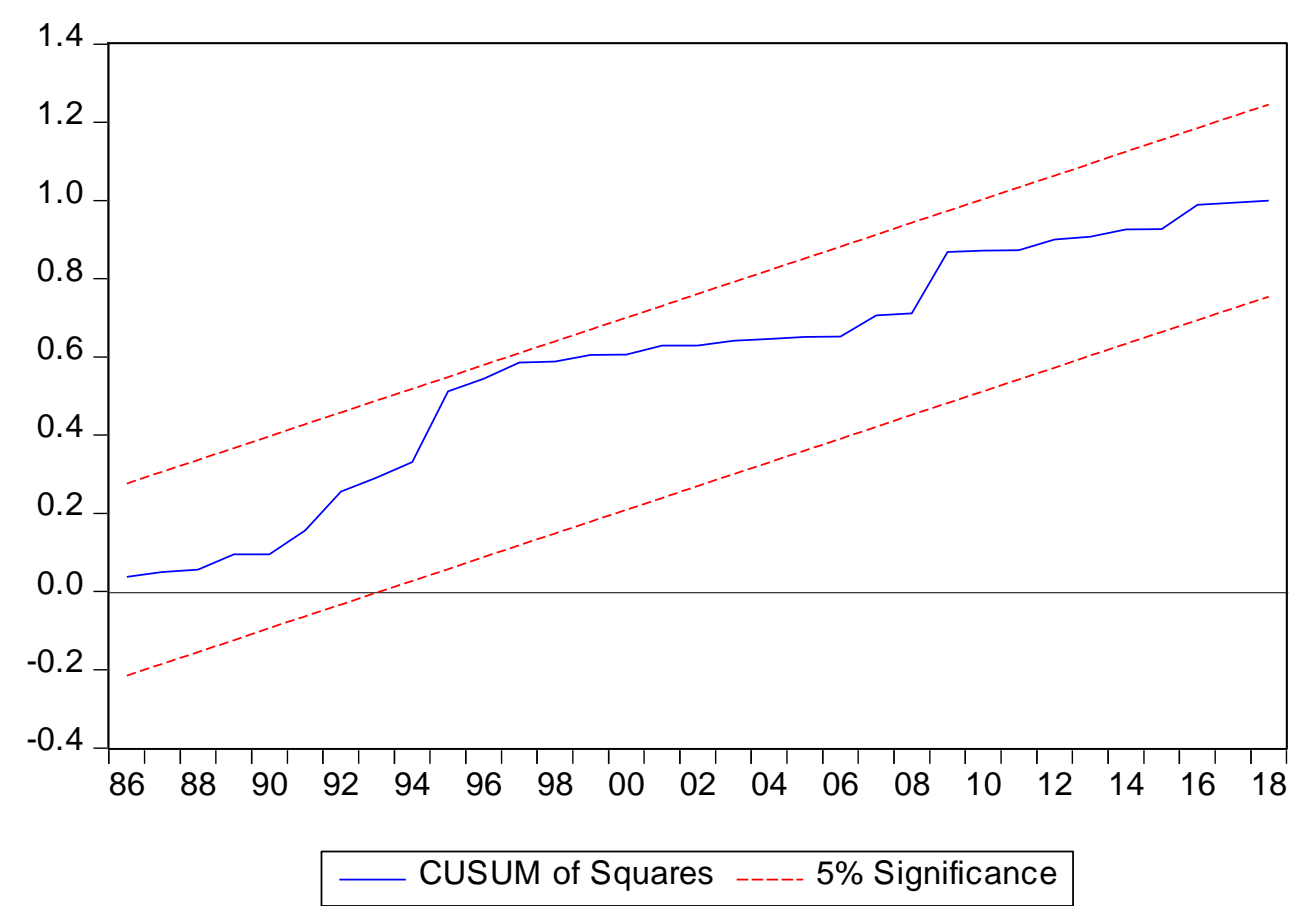

Figure 3. CUSUM of squares test

\section{Copyrights}

Copyright for this article is retained by the author(s), with first publication rights granted to the journal.

This is an open-access article distributed under the terms and conditions of the Creative Commons Attribution license (http://creativecommons.org/licenses/by/4.0/). 